\title{
Use of biological glue to control pulmonary air leaks
}

\author{
Adel F Matar, Jonathan G Hill, William Duncan, Nicholas Orfanakis, Ivan Law
}

\begin{abstract}
Biological glue is a natural adhesive generated by the interaction between fibrinogen (pre-glue) and thrombin to produce fibrin. The pre-glue is prepared from a single donor (to avoid the problems of pooled plasma) and stored as cryoprecipitate. Before being used it is thawed, dissolved in saline, and activated into an adhesive by the addition of topical thrombin. Biological glue was used prophylactically to prevent air leaks from bronchial suture lines and raw lung surfaces after pulmonary resections in six patients. In addition two new methods of using biological glue have been developed for the control of persisting air leaks. In selective intrabronchial tamponade the glue is instilled into the bronchial tree through a flexible bronchoscope, and in therapeutic pleurodesis it is instilled into the pleural cavity through a chest drainage tube. The air leaks were resolved in all cases. Seven procedures using selective intrabronchial tamponade were carried out in six patients. Four were immediately successful but three were not and required further interventions. Therapeutic pleurodesis alone was successfully carried out in one patient and as an adjunct to selective intrabronchial tamponade on two occasions. A thoracotomy was eventually needed in one of the seven patients.
\end{abstract}

Biological glue (fibrinogen (pre-glue) plus thrombin) has been extensively used in Europe to control bleeding from cardiac and vascular suture lines ${ }^{1}$ and from vascular prostheses. $^{2-4}$ It has also been used to prevent dehiscence, leaks, and stricture formation after anastomosis of the common bile duct. ${ }^{5}$

The surface application of fibrin adhesive to control pulmonary air leaks in experimental animals was reported by Turk et al, ${ }^{6}$ and these authors have used fibrin adhesive intraoperatively to control air leaks from pulmonary suture lines. ${ }^{6}$ They concluded that the adhesive substantially increased the tolerance of suture lines to high airway pressure. Selective intrabronchial injection of biological glue in an attempt to achieve immediate seal of an air leak has not been reported.

The adhesive property of fibrin occurs in the final stages of the coagulation cascade (fig 1). The pre-glue is a fibrinogen concentrate, prepared from whole blood, plasma, or cryoprecipitate. Preparation of pre-glue from the patient's own blood would be ideal but is not practical. The commercial preparation (Tissell: Immuno Company, Vienna) is prepared from pooled plasma. This preparation is banned in the United States because of the risk of transmission of hepatitis $B$, the acquired immune deficiency syndrome, and other infections.

\section{Methods}

PREPARATION OF BIOLOGICAL GLUE

We have prepared our pre-glue from dry button cryoprecipitate obtained from a single donor prepared and given to us by the Red Cross. Dry button differs from the standard cryoprecipitate in that all plasma is removed before storage. The amount of fibrinogen available in our preparation was found to be fairly constant at about $60 \mathrm{mg}$ per unit of cryoprecipitate. When the glue is needed, one unit of cryoprecipitate is thawed at $37^{\circ} \mathrm{C}$ and dissolved in $5 \mathrm{ml}$ normal saline; it is ready for use in five minutes. The pre-glue is activated into adhesive by the addition of topical thrombin.

\section{TECHNIQUE}

Intraoperative prophylactic surface application of fibrin glue

All major air leaks must be controlled by sutures or ligatures. The lung must be deflated and ventilation discontinued. Vesicular air leaks from resected surface are then controlled by spraying the surface with pre-glue from a syringe with a $16 \mathrm{~F}$ plastic cannula followed by topical thrombin from another syringe. Alternatively, the pre-glue may be spread over thin sheets of oxycel cotton, which are applied to the leaking surface and then sprayed with topical thrombin. It is preferable not to restart ventilation for three minutes and a double lumen endotracheal tube is therefore advantageous. If a single lumen tube is used, ventilation can be restarted gently in one minute and fully after three minutes.

For prophylactic use over bronchial suture lines the pre-glue is sprayed on a thin sheet of oxycel cotton applied to the suture line, and this is followed by a spray of thrombin from a syringe. The use of large amounts of thrombin tends to wash away the pre-glue. The appropriate ratio of thrombin to preglue is 1:4. A pleural patch could be used instead of oxycel over the adhesive glue. It will stick without the need for sutures. 
Figure 1 Coagulation cascade.

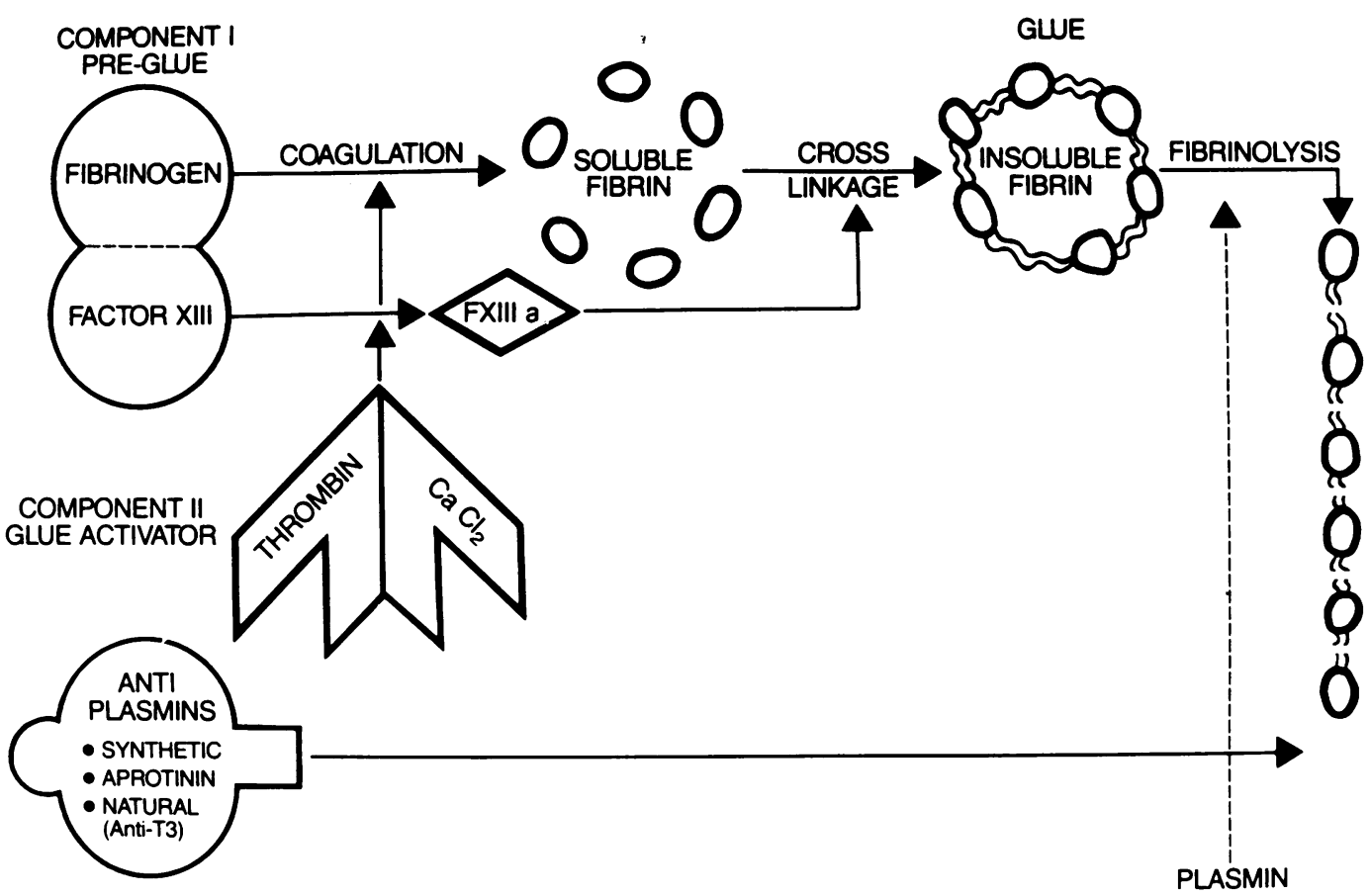

Selective intrabronchial tamponade with fibrin glue

Selective intrabronchial tamponade with fibrin glue is done under general intravenous anaesthesia and endotracheal intubation with an 8-9 $\mathrm{mm}$ endotracheal tube. A large channel fibreoptic flexible bronchoscope is passed through the endotracheal tube to the segmental bronchus suspected of being the source of the air leak. After the area is cleared of mucus, an $8 \mathrm{~F}$ diagnostic two channel Swan Ganz catheter is passed through the suction channel of the bronchoscope into the suspected segmental bronchus and advanced for $2 \mathrm{~cm}$ (fig 2 ). The balloon is then inflated. If the air leak stops positive inflation pressure up to $30 \mathrm{~cm}$ of water is then applied by the anaesthetist and maintained for 30 seconds to confirm that the leak is occluded. If the selected bronchus is not the source of the leak, the same procedure is repeated after the catheter has been passed

Figure 2 Technique of selective intrabronchial tamponade.

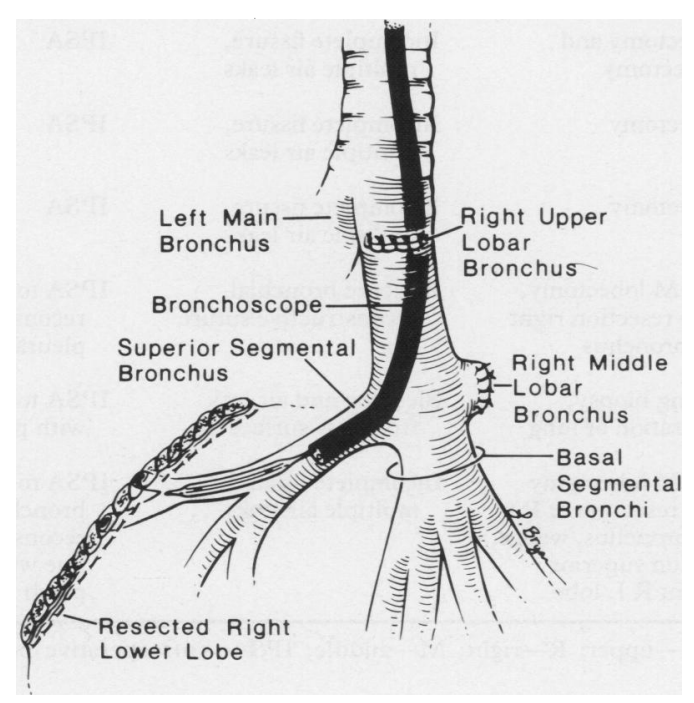

into another segmental bronchus. Once the correct bronchus has been identified, $2 \mathrm{ml}$ of pre-glue is injected through the catheter lumen followed by $2 \mathrm{ml}$ of air. This is followed by injection of $0.5 \mathrm{ml}$ (500 units) of topical thrombin, again followed by $2 \mathrm{ml}$ of air, and then $1 \mathrm{ml}$ of $\varepsilon$ aminocaproic acid (Amicar) and $2 \mathrm{ml}$ of air. The balloon is kept inflated for three minutes, after which it is deflated and the catheter is withdrawn from the suction channel. The bronchoscope is then withdrawn for $1 \mathrm{~cm}$ and the area of injection visualised. The competence of the seal is finally tested by inflation at $30 \mathrm{~cm}$ sustained positive pressure by the anaesthetist. No air leak should occur.

Some important rules must be followed to increase the chances of success:

1 The operator must ensure at the outset of the procedure that the patient is the source of the leak. The chest tube should be clamped close to the chest wall and this should eliminate the leak in the presence of continuous suction. If the leak does not stop it must be coming from the chest tube drain and not from the patient.

2 The bronchial tree must be kept dry. This may be achieved by giving atropine $0.3 \mathrm{mg}$ intravenously, and repeating this if necessary. Intravenous anaesthesia is preferable as inhaled anaesthetic agents are likely to increase secretions and obscure visibility.

3 The air leak must be continuous while the chest tube is on suction. Inflation of the balloon inside a specific segmental bronchus must abolish or substantially reduce the leak.

Therapeutic pleurodesis by application of fibrin glue through the chest tube

The patient is placed in the lateral supine position with the leaking side up. Ten millilitres of pre-glue is injected through the chest 
chest tube and the tube is clamped. The patient's position is changed every minute to allow the glue to spread over the surface of the lung. Four millilitres of thrombin is injected and the patient's position is changed as before. The clamp is removed after three minutes, after which the air leak should have stopped completely or been substantially reduced. If this is not achieved the whole process should be repeated. Unless there are two chest tubes, the chest tube used for introducing the fibrin glue should be irrigated with saline; otherwise it may become obstructed, causing the lung to collapse and surgical emphysema to develop if the leak is not controlled. If the patient is being ventilated mechanically the injections should be made during deflation of the lungs. Deflation should be maintained for as long as possible before ventilation is resumed. Short acting muscle relaxants may be used to permit complete control.

\section{Patients}

Intraoperative prophylactic surface application of biological glue

Six patients were treated with biological glue by this technique (details in table 1). Five with chronic obstructive pulmonary disease underwent resection of one or more lobes for bronchogenic carcinoma. In three patients incomplete fissures led to multiple air leaks at the conclusion of the operation and these were treated with an intraoperative prophylactic application of fibrin glue. In one patient who had had a wedge resection of the right main bronchus biological glue and a pleural patch were applied prophylactically to the reconstruction suture line; in the fifth patient the pulmonary air leak was treated with glue and the bronchial reconstruction suture line with both glue and a pleural patch. The final patient had an open lung biopsy for a pulmon- ary infiltrate and both bleeding and air leak were controlled with glue, which also helped to keep a pleural patch glued to the raw surface of the lung.

\section{Selective intrabronchial tamponade}

Details of the six patients having intrabronchial tamponade are shown in table 2. The first patient had a persistent air leak after resection of bronchial carcinoma. Five had pneumothoraces with persisting air leaks, two with a background of chronic obstructive pulmonary disease and one with pulmonary lymphangioleiomyomatosis. Six procedures were carried out on these five patients. A contralateral procedure was carried out in patient 5 after two months.

\section{Therapeutic pleurodesis}

In the patient having therapeutic pleurodesis lung resection was undertaken for bronchogenic carcinoma in the presence of an incomplete major fissure. There were minimal vesicular air leaks but these persisted for seven days. Fibrin glue therapeutic pleurodesis led to a complete cessation of the air leak within 24 hours (table 3 ).

\section{Results}

Intraoperative prophylactic surface application of biological glue

An intraoperative prophylactic surface application of biological glue, alone or in conjunction with a pleural patch, was used in six patients in whom a prolonged postoperative air leak was anticipated. After these procedures there were no air leaks. All chest tubes were removed within 24 hours and none of the patients remained in hospital for more than seven days (table 1).

Table 1 Details of patients who had intraoperative prophylactic surface application of biological glue

\begin{tabular}{|c|c|c|c|c|c|c|}
\hline $\begin{array}{l}\text { Patient } \\
\text { No }\end{array}$ & $\begin{array}{l}\text { Age }(y), \\
\text { sex }\end{array}$ & Diagnosis & Operation & Problem & Procedure & Result \\
\hline 1 & $55, M$ & $\begin{array}{l}\text { COPD, bronchogenic } \\
\text { carcinoma }\end{array}$ & $\begin{array}{l}\text { LU lobectomy and } \\
\text { lingulectomy }\end{array}$ & $\begin{array}{l}\text { Incomplete fissure, } \\
\text { multiple air leaks }\end{array}$ & IPSA & $\begin{array}{l}\text { No post-op } \\
\text { air leak }\end{array}$ \\
\hline 2 & $66, M$ & $\begin{array}{l}\text { COPD, bronchogenic } \\
\text { carcinoma }\end{array}$ & RU lobectomy & $\begin{array}{l}\text { Incomplete fissure, } \\
\text { multiple air leaks }\end{array}$ & IPSA & $\begin{array}{l}\text { No post-op } \\
\text { air leak }\end{array}$ \\
\hline 3 & $62, \mathrm{~F}$ & $\begin{array}{l}\text { COPD, bronchogenic } \\
\text { carcinoma }\end{array}$ & RU lobectomy & $\begin{array}{l}\text { Incomplete fissure, } \\
\text { multiple air leaks }\end{array}$ & IPSA & $\begin{array}{l}\text { No post-op } \\
\text { air leak }\end{array}$ \\
\hline 4 & $59, M$ & $\begin{array}{l}\text { COPD, bronchogenic } \\
\text { carcinoma }\end{array}$ & $\begin{array}{l}\text { RU and } M \text { lobectomy, } \\
\text { wedge resection right } \\
\text { main bronchus }\end{array}$ & $\begin{array}{l}\text { Insecure bronchial } \\
\text { reconstructive suture } \\
\text { line }\end{array}$ & $\begin{array}{l}\text { IPSA to bronchial } \\
\text { reconstruction with } \\
\text { pleural patch }\end{array}$ & $\begin{array}{l}\text { No post-op } \\
\text { air leak }\end{array}$ \\
\hline 5 & $61, M$ & Pulmonary infiltrate & $\begin{array}{l}\text { Open lung biopsy, } \\
\text { hepatisation of lung }\end{array}$ & $\begin{array}{l}\text { Bleeding and air leak } \\
\text { from raw surface }\end{array}$ & $\begin{array}{l}\text { IPSA to lung surface } \\
\text { with pleural patch }\end{array}$ & $\begin{array}{l}\text { No post-op } \\
\text { air leak }\end{array}$ \\
\hline . & $61, F$ & $\begin{array}{l}\text { COPD, bronchogenic } \\
\text { carcinoma, } 7 \text { rounds of } \\
\text { chemotherapy }\end{array}$ & $\begin{array}{l}\text { RU and } M \text { lobectomy } \\
\text { sleeve resection of } R \\
\text { main bronchus, wedge } \\
\text { resection superior } \\
\text { segment } R \text { L lobe }\end{array}$ & $\begin{array}{l}\text { Incomplete fissure, } \\
\text { mulltiple air leaks }\end{array}$ & $\begin{array}{l}\text { IPSA to lung and to } \\
\text { bronchial } \\
\text { reconstruction suture } \\
\text { line with pleural } \\
\text { patch }\end{array}$ & $\begin{array}{l}\text { No post-op } \\
\text { air leak }\end{array}$ \\
\hline
\end{tabular}

COPD—chronic obstructive pulmonary disease; L-left; U-upper; R-right; $M$-middle; IPSA-intraoperative prophylactic surface application; post-op-postoperative. 
Table 2 Details of patients who had selective intrabronchial tamponade with biological glue

\begin{tabular}{|c|c|c|c|c|c|c|}
\hline $\begin{array}{l}\text { Patient } \\
\text { No }\end{array}$ & $\begin{array}{l}\operatorname{Age}(y) \\
\operatorname{sex}\end{array}$ & Diagnosis & Operation & Problem & Procedure & Result \\
\hline 1 & $77, \mathrm{~F}$ & $\begin{array}{l}\text { Bronchogenic } \\
\text { carcinoma }\end{array}$ & $\begin{array}{l}\text { RU and } M \text { lobectomy, } \\
\text { wedge resection } R L \\
\text { lobe }\end{array}$ & $\begin{array}{l}\text { Persistent air leak } 3 \\
\text { weeks }\end{array}$ & $\begin{array}{l}\text { SIBT superior } \\
\text { segment, RL lobe }\end{array}$ & Instant control \\
\hline 2 & $40, M$ & $\mathrm{R}$ pneumothorax & Insertion of chest tube & $\begin{array}{l}\text { Intermittent persistent } \\
\text { air leak } 7 \text { days }\end{array}$ & SIBT RU lobe & $\begin{array}{l}\text { Failed; required } \\
\text { thoracotomy }\end{array}$ \\
\hline 3 & $51, \mathrm{~F}$ & $\begin{array}{l}\text { COPD, recurrent } \\
\text { spontaneous } \\
\text { pneumothorax }\end{array}$ & Insertion of chest tube & $\begin{array}{l}\text { Persistent air leak } 25 \\
\text { days }\end{array}$ & $\begin{array}{l}\text { SIBT RU lobe apical } \\
\text { segment }\end{array}$ & $\begin{array}{l}\text { Immediate control of } \\
\text { air leak }\end{array}$ \\
\hline 4 & $71, M$ & $\begin{array}{l}\text { COPD (with home } \\
\text { oxygen), } R \\
\text { pneumothorax }\end{array}$ & Insertion of chest tube & $\begin{array}{l}\text { Persistent air leak } 36 \\
\text { days }\end{array}$ & $\begin{array}{l}\text { SIBT: failed to enter } \\
\text { offending segmental } \\
\text { bronchus; TP and } \\
\text { SIBT repeated after } \\
48 \text { hours with } \\
\text { fluoroscopy: } \\
\text { offending } \\
\text { subsegmental } \\
\text { bronchus entered and } \\
\text { tamponade added }\end{array}$ & $\begin{array}{l}\text { Leak slowed but } \\
\text { recurred after } 24 \mathrm{~h} \\
\text { - }\end{array}$ \\
\hline \multirow[t]{3}{*}{5} & \multirow[t]{3}{*}{$27, \mathrm{~F}$} & $\begin{array}{l}\text { Bilateral pulmonary } \\
\text { lymphangioleio- } \\
\text { myomatosis, L } \\
\text { pneumothorax; }\end{array}$ & Insertion of chest tube & $\begin{array}{l}15 \text { bilateral } \\
\text { spontaneous } \\
\text { pneumothoraces; } \\
\text { now has persistent air } \\
\text { leak }\end{array}$ & $\begin{array}{l}\text { SIBT to apical segment } \\
\text { LU lobe }\end{array}$ & $\begin{array}{l}\text { Air leak stopped, } \\
\text { recurred after } 48 \mathrm{~h} \text {, } \\
\text { stopped again after } \\
\text { insertion of chest } \\
\text { tube }\end{array}$ \\
\hline & & $\begin{array}{l}\text { R pneumothorax } 2 \\
\text { months later; }\end{array}$ & Insertion of chest tube & Persistent air leak & SIBT RU lobe & Air leak stopped \\
\hline & & $\begin{array}{l}\text { R pneumothorax } 6 \\
\text { months later }\end{array}$ & Insertion of chest tube & Persistent air leak & $\begin{array}{l}\text { SIBT anterior segment } \\
\text { RU lobe }\end{array}$ & Immediate control \\
\hline 6 & $26, M$ & $\begin{array}{l}\text { Spontaneous } \\
\text { pneumothorax after } \\
\text { diving }\end{array}$ & Insertion of chest tube & $\begin{array}{l}\text { Persistent air leak } 5 \\
\text { days }\end{array}$ & $\begin{array}{l}\text { SIBT R apico- } \\
\text { posterior segment }\end{array}$ & Immediate control \\
\hline
\end{tabular}

SIBT-Selective intrabronchial tamponade; TP-therapeutic pleurodesis. Other abbreviations as in table 1.

Selective intrabronchial tamponade

Six patients had selective intrabronchial tamponade, nine procedures being performed. Six of the procedures were immediately successful in controlling the air leak and the patients were able to leave the hospital promptly (table 2); a contralateral pneumothorax occurred in the patient with lymphangioleiomyomatosis two months later. Three procedures were not successful. In patient 2 a thoracotomy was required and an apical bleb was excised and oversewn. In patient 4 , selective intrabronchial tamponade was repeated under fluoroscopic control, which permitted the leaking bronchus to be entered, and tamponade was carried out successfully. In patient 5 the procedure was successful initially but the air leak recurred and then stopped spontaneously after insertion of a chest tube. The procedure on the other side in this patient was carried out two months later and was successful initially, but the pneumothorax recurred after six months; it was treated immediately and successfully with a further selective intrabronchial tamponade.

\section{Therapeutic pleurodesis}

Therapeutic pleurodesis was used successfully in one patient (table 3 ) and as an adjunct to selective intrabronchial tamponade twice in one other patient (table 2).

\section{Discussion}

Biological glue has been available commercially and used in Europe for controlling bleeding in cardiac and vascular operations, for presealing porous prosthetic material, and for enhancing the tissue adhesion and pressure tolerance of anastomatic suture lines. The commercial product prepared from pooled plasma has been banned from the United States because of the risk of transmission of hepatitis, the acquired immune deficiency syndrome, and other blood transmitted infections. We have found that a single donor unit of cryoprecipitate, thawed and dissolved in $5 \mathrm{ml}$ normal saline, provides an excellent pre-glue with a high concentration of fibrinogen in addition to factor VIII. The preglue is activated by adding topical thrombin

Table 3 Details of the patient who had therapeutic pleurodesis

\begin{tabular}{llllll}
\hline Age $(y)$, sex & Diagnosis & Operation & Problem & Procedure & Result \\
\hline $55, \mathrm{M}$ & $\begin{array}{c}\text { Bronchogenic } \\
\text { carcinoma }\end{array}$ & $\begin{array}{c}\text { RU and } \mathrm{M} \\
\text { lobectomy }\end{array}$ & $\begin{array}{c}\text { Incomplete major fissure, } \\
\text { persistent air leak 7 days }\end{array}$ & TP & Leak stopped \\
\hline
\end{tabular}

TP-therapeutic pleurodesis. 
containing calcium chloride. A soluble fibrin compound is formed, which is then polymerised into insoluble fibrin; this achieves maximal strength in three minutes.

In this series the fibrin glue was used either prophylactically on the surface of the lung or suture lines or therapeutically by intrabronchial tamponade alone or supplemented by fibrin glue pleurodesis. Pleurodesis was the only therapeutic measure in one case. The fate of the glue has not been studied but in one case there was visual evidence of subsequent fibrinolysis. We therefore added an antifibrinolytic agent in subsequent cases.

We have considered the following possible causes of failure of biological glue in our patients:

1 Excessive secretions cause lubrication of the bronchial walls. This may allow the intrabronchial plug to fall out of position and be expectorated.

2 Excessive fibrinolysis is a suspected cause of delayed failure as air leaks recurred in two patients within 24 hours after initial success. Since then we have added the antifibrinolytic agent $\varepsilon$ aminocaproic acid to the site of selective intrabronchial tamponade.

3 We believe that the tamponade effect occurs at bronchial level. Intersegmental and interlobar alveolar connections, which may be larger in patients with severe emphysema, could increase the failure rate.

4 It may be difficult to enter the correct segment. Failure to enter the segmental bronchus leading to the leaking bleb occurred in one case and was demonstrated with the use of radiopaque dye and fluoroscopy.
5 Compressed air trapped in lung peripheral to the tamponaded bronchus could cause a low grade leak for some time despite successful occlusion of the supplying bronchus. The leak may not stop until the trapped air is evacuated. In one of our cases the leak stopped 24 hours after intrabronchial tamponade.

In this series of patients fibrin glue was successful in controlling air leaks in all cases when used prophylactically. When used therapeutically it was successful initially in four patients and after a repeat procedure in two more. Thus we avoided thoracotomy in six of the seven patients.

The use of this preparation poses no more hazard to the patient than the transfusion of one unit of cryoprecipitate. We feel it merits further application and study of its use for control of air leaks. Its adhesive properties are impressive and it has the potential for dramatic reduction in morbidity and in the cost of thoracic operations that include lung resection.

1 Lupinetti FM, Stoney WS, Alford WC, et al. Cryoprecipitate-topical thrombin glue. J Thorac Cardiovasc Surg 1985;90:502-5.

2 Borst HG, Haverich A, Walterbusch G, Maatz W. Fibrin Adhesive. An important hemostatic adjunct on cardiovascular operations. $J$ Thorac Cardiovasc Surg 1983;84 548-53.

3 Jakob MD, Campbell CD, Qiu Z-K, et al. Evaluation of fibrin sealing for cardiovascular surgery. Circulation 1984 70(suppl I): 138-45.

4 Dresdale A, Rose EA, Jeevanandam V, et al. Preparation of fibrin glue from single-donor fresh-frozen plasma. Surgery 1985;97:750-4.

5 Kram HG, Garces MA, Klein SR, et al. Common bile duct anastomosis using fibrin glue. Arch Surg Vol 120:1250-6, November, 1985.

6 Turk R, Weidringer JW, Hartel W, Blumel G. Closure of lung leaks by fibrin gluing. Experimental investigations and clinical experience. Thorac Cardiovasc Surg 1983;31: 185-6. 